\title{
EUROPEAN REGULATION ON VEHICLE REAL DRIVING EMISSIONS CONTROL
}

\author{
Velimir Petrović ${ }^{1}$, Stojan Petrović
}

UDC: $629.341 ; 629.3 .078$

DOI: $10.24874 / \mathrm{mvm} .2017 .43 .02 .04$

\begin{abstract}
The paper discusses the actual problem of $\mathrm{NO}_{\mathrm{x}}$ emission in real driving conditions. In the first part of the paper the existing situation in regard to the $\mathrm{NO}_{\mathrm{x}}$ emission of light vehicles in real use is presented using the tests performed all around Europe. Since the obtained emission is several times higher than existing limits according EU standards, the main causes for such differences have been analysed. Special attention is paid at the use of defeat devices applied by many car manufacturers using certain emission control strategy at approval test to obtain low emissions and another control strategy in real driving to obtain good fuel economy. To prevent excessive emission in real use, EU Commission has undertaken regulatory measures to accept new regulation which defines new limits for $\mathrm{NO}_{\mathrm{x}}$ emission in real use as well as control testing the light vehicles in real driving conditions.
\end{abstract}

KEY WORDS: passenger cars, exhaust emissions, regulation, real driving, $\mathrm{NO}_{\mathrm{x}}$

\section{EVROPSKI PROPISI O KONTROLI EMISIJE VOZILA U STVARNOJ VOŽNJI}

REZIME: U radu se razmatra aktuelni problem emisije NOx u stvarnim uslovima vožnje. U prvom delu se prikazuje postojeća situacija u pogledu emisije NOx lakih vozila u stvarnoj eksploataciji koristeći rezultate ispitivanja obavljenih širom Evrope. Pošto je izmerena emisija nekoliko puta veća od granica propisanih standardom, analiziraju se glavni uzroci tih razlika. Posebna pažnja se poklanja primeni uređaja za promenu kontrolne strategije kod mnogih proizvođača vozila kada se koristi jedna strategija za kontrolu emisije pri homologacionom ispitivanju u cilju dobijanja niske emisije, a druga kontrolna strategija u stvarnoj eksploataciji u cilju postizanja povoljne ekonomičnosti goriva. Kako bi se spečila preterana emisija u stvarnoj eksploataciji, Evropska Komisija je preduzela korake ka stvaranju propisa koji bi definisali nove granice dozvoljene emisije $\mathrm{NO}_{\mathrm{x}} \mathrm{u}$ stvarnoj eksploataciji kao i kontrolno ispitivanje lakih vozila u stvarnim uslovima vožnje.

KLJUČNE REČI: putnička vozila, izduvna emisija, propisi, stvarna vožnja, $\mathrm{NO}_{\mathrm{x}}$

${ }^{1}$ Received February 2017, Accepted March 2017, Published On Line June 2017

Volume 43, Number 2, 2017 
Intentionally blank 


\title{
EUROPEAN REGULATION ON VEHICLE REAL DRIVING EMISSIONS
}

\author{
Velimir Petrović ${ }^{1}$, Stojan Petrovic ${ }^{2}$
}

\section{INTRODUCTION}

Euro 6 standards entered into force at the end of 2014. The main novelty in them in relation to the Euro 5 was significant reduction of $\mathrm{NO}_{\mathrm{x}}$ emission limits for light vehicles (passenger cars - PC and light duty vehicles - LDV) with diesel engines: from $180 \mathrm{mg} / \mathrm{km}$ to $80 \mathrm{mg} / \mathrm{km}$. This reduction is practically equalized nitric oxides $\left(\mathrm{NO}_{\mathrm{x}}\right)$ emissions of light vehicles with gasoline and diesel engines (Figure 1) [1].

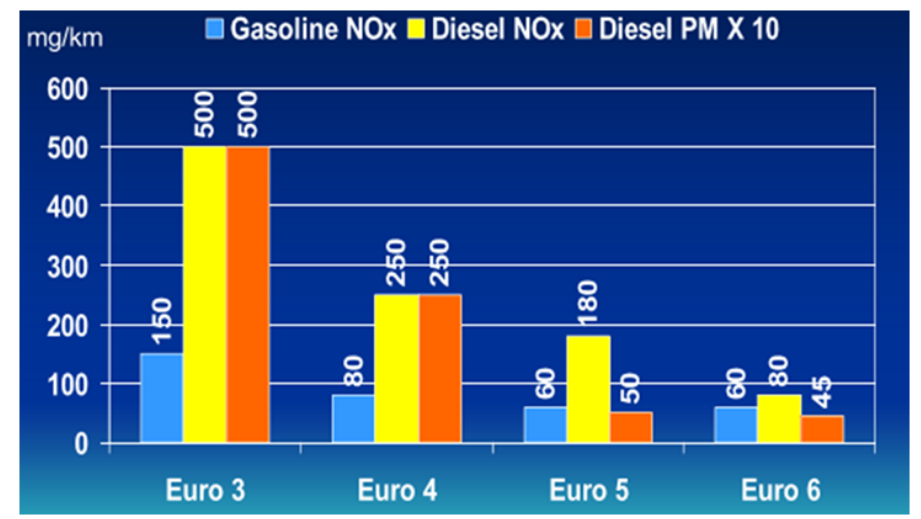

Figure 1 EU standards on $\mathrm{NO}_{x}$ and Particulate Maters (PM) for light vehicles

Gasoline $\mathrm{NO}_{\mathrm{x}}$ limits were significantly lower than diesel $\mathrm{NO}_{\mathrm{x}}$ limits until Euro 6 standard [2]. Actually, to reach $\mathrm{NO}_{\mathrm{x}}$ limits it was much easier to gasoline engines than to diesel engines. Application of three way catalyst (TWC) technology for gasoline engines successfully solves the problem of $\mathrm{NO}_{\mathrm{x}}$ emission, as well as $\mathrm{CO}$ and $\mathrm{HC}$ emissions, allowing very small limits. However, it is very difficult for diesel engine to find a solution that successfully reduces at the same time particulate matters $\mathrm{PM}$ and $\mathrm{NO}_{\mathrm{x}}$.

Euro 5 standard [2] was generally requested drastically reduction of diesel engine particles emission and therefore introduced almost mandatory application of diesel particulate filter (DPF). The $\mathrm{NO}_{\mathrm{x}}$ emission was only slightly reduced by this standard, but to achieve the required limits it was necessary further diesel engine improvement and the application of additional solutions, primarily exhaust gas recirculation (EGR) and eventually lean $\mathrm{NO}_{\mathrm{x}}$ trap $(\mathrm{LNT})$.

\footnotetext{
${ }^{1}$ Velimir Petrović, Ph.D., IMR Institute d.o.o., 11090 Patrijaha Dimitrija 7. Belgrade, Serbia, imrinstitut@eunet.rs

${ }^{2}$ Stojan Petrović, Ph.D., prof., University of Belgrade, Faculty of Mechanical Engineering, 11000 Kraljice Marije 16; Tehnolab, Centre for Motor Vehicle, Turgenevljeva 3, Beograd, pe_trost@live.com.
} 
Euro 6 standard has significantly reduced $\mathrm{NO}_{\mathrm{x}}$ emissions of diesel engines by about 60\%. New limits for $\mathrm{NO}_{\mathrm{x}}$ required more sophisticated solutions such as electronically regulated cool exhaust gas recirculation (EGR), lean $\mathrm{NO}_{\mathrm{x}}$ trap (LNT) or selective catalytic reactor (SCR). Although SCR is the most efficient technology for reduction of $\mathrm{NO}_{\mathrm{x}}$ emissions, this solution have not found wide application in passenger vehicles because of its complexity and higher costs. Therefore, in the domain of passenger vehicles mainly dominates the application of EGR with a possible addition of LNT. However, the efficiency of the EGR system is not too big and a higher decrease of $\mathrm{NO}_{\mathrm{x}}$ reduction can jeopardize the economy of the engine.

\section{REAL DRIVING EMISSIONS OF PASSENGER CARS}

Unfortunately it turned out that the exhaust emissions of vehicles in real driving conditions can be significantly higher than the limits defined by standards. Figure 2 shows mean $\mathrm{NO}_{\mathrm{x}}$ emission factors (values in $\mathrm{g} / \mathrm{km}$ converted in $\mathrm{g} / \mathrm{kg}$ fuel using measured fuel consumption rates) of gasoline (left) and diesel (right) passenger cars (PC) and light commercial vehicles (LCV) as a function of model year [3]. $\mathrm{NO}_{\mathrm{x}}$ emission is measured in test cycle that represents real driving conditions. Obtained mean values during the test of different model year vehicles are presented with $95 \%$ confidence interval over the mean.

Actually it was concluded that passenger vehicles with gasoline engines do not have a lot of problems with exhaust emission in real use since TWC technology is very effective, especially with normally warmed engine. Therefore, the emissions in normal driving conditions correspond very well to the emissions obtained during approval test.

In the case of passenger cars with diesel engine a situation is much worse. Though the $\mathrm{NO}_{\mathrm{x}}$ emission limits were constantly diminished, the emission in real driving conditions stayed almost the same. Therefore the gap between test and real driving results for diesel engines was very big. Figure 3 schematically illustrates the comparison between approval limits and real driving $\mathrm{NO}_{\mathrm{x}}$ emissions for different classes of vehicles. Actually diesel engines $\mathrm{NO}_{\mathrm{x}}$ emission in real driving conditions can be higher than limits by a factor of 2 for Euro 3 cars, more than 3 times for Euro 4, and more than 4 times for Euro 5 [4]. It was believed that the main reasons for the observed gap were different test and real conditions.
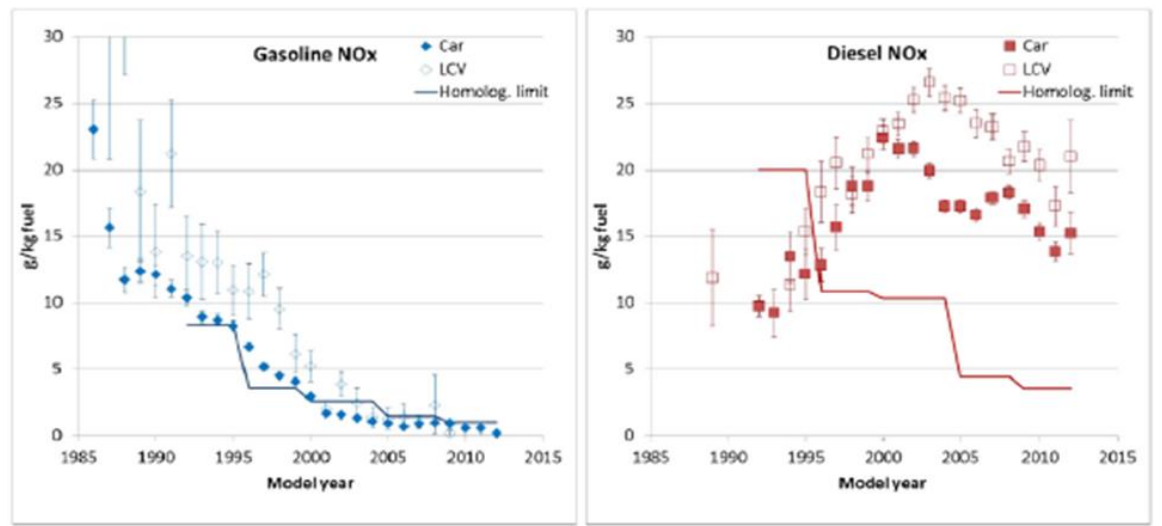

Figure 2 Mean hot NOx emission of gasoline (left) and diesel (right) passenger cars and light commercial vehicles ( $L C V)$ as a function of model year [3] 

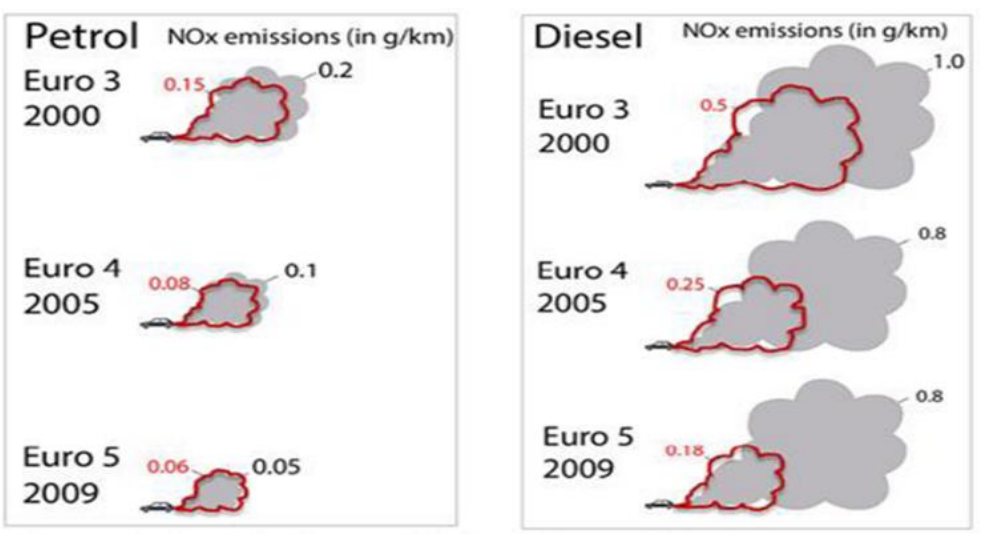

Figure 3 Test and real driving results (red-approval limits, black - real drive) [4]

However, the situation became more serious when in September 2015 the U.S. EPA and the California Air Resources Board announced that a number of VW 2.0L diesel vehicle models sold in the U.S. during model years 2009 to 2015 was equipped with illegal defeat devices. The EPA issued a second notice of violation in November 2015 for VW model year 2009-2016 vehicles equipped with 3.0L diesel engines stating that "VW manufactured and installed software in the electronic control module (ECM) of each vehicle that causes the vehicle to perform differently when the vehicle is being tested for compliance with EPA emission standards than in normal operation and use." While the description of the defeat device was more detailed than in the September notice of violation, in both cases the vehicles were operating under two emissions control regimes: one during emissions testing, and one at other times. The EPA described the defeat device used in the 3.0L vehicles as software that determines when the vehicle has begun the FTP 75 certification test and then employs a low- $\mathrm{NO}_{\mathrm{x}}$ temperature conditioning mode, varying a number of engine parameters to yield lower engine-out [5].

Having in mind critical situation and knowing that also a lot of other European vehicles have high emissions in real driving conditions, from the beginning of 2015 started in Europe intensive testing of real driving exhaust emissions of passenger cars (PC) and light commercial vehicles (LCV). Tests have been performed in laboratories simulating real driving conditions, as well as on roads in real traffic.

It was found [6] that over four in five cars that meet the Euro 5 standard for $\mathrm{NO}_{\mathrm{x}}$ in the laboratory $(180 \mathrm{~g} / 1000 \mathrm{~km})$, and were sold between 2010-2014.years, actually produce more than three times this level when driven on the road. Also two-thirds of Euro 6 cars (most on sale since 2015) still produce more than three times the $80 \mathrm{~g} / 1000 \mathrm{~km}$ limit when driven on the road.

When Euro 6 vehicles first entered the market in 2014 they typically produced in real use around $600 \mathrm{mg} / \mathrm{km}$ of $\mathrm{NO}_{\mathrm{x}}$ or 7.5 times the $80 \mathrm{mg} / \mathrm{km}$ limit. More recent models are better, typically 5.5 times the limit $(440 \mathrm{mg} / \mathrm{km})$. However, some models' exceedances are over 10 times. It is estimated that about $80 \%$ of total registered Euro 5 vehicles and about $64 \%$ of Euro 6 diesel cars exceed existing $\mathrm{NO}_{\mathrm{x}}$ limits [6].

According to the performed tests in last year and recently published results on $\mathrm{NO}_{\mathrm{x}}$ exhaust emission in real driving conditions there are a lot of cars manufacturers which sold cars with higher emissions than declared level at approval test. For Euro 5 cars, the five 
worst performing companies were (in order of the highest emissions): Renault (including Dacia), Land Rover, Hyundai, Opel/Vauxhall (including Chevrolet) and Nissan. The best performing Euro 5 cars were made by (in order of lowest emissions): Seat, Honda, BMW (including Mini), Ford and Peugeot. For current Euro 6 cars a different pattern emerges. The worst performers are: Fiat (including Alfa Romeo + Suzuki to whom Fiat supply engines); Renault (including Nissan, Dacia and Infiniti); Opel/Vauxhall; Hyundai; and Mercedes. The cleanest Euro 6 car is VW Group with VW cars, followed by Seat, Skoda and Audi; BMW (including Mini) and Mazda [6]. Fig. 4 illustrates this situation using the EQUA Air Quality Index results on real-world emissions data.

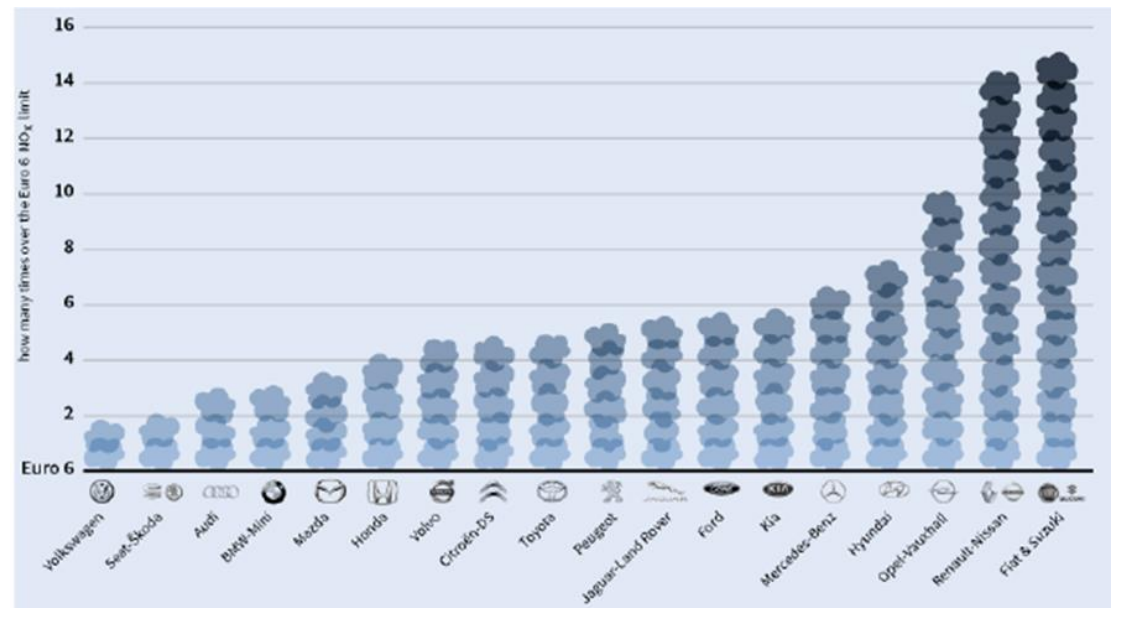

Figure 4 Euro 6 manufacturers (selling cars in Europe) over approval limits rated according their average real driving emissions index [6]

Similar situation is also in United Kingdom. Fig. 5 shows the results of tested used cars taken from rent companies in England. Euro 5 cars have six time greater emission than limits and Euro 6 cars seven times exceedance.
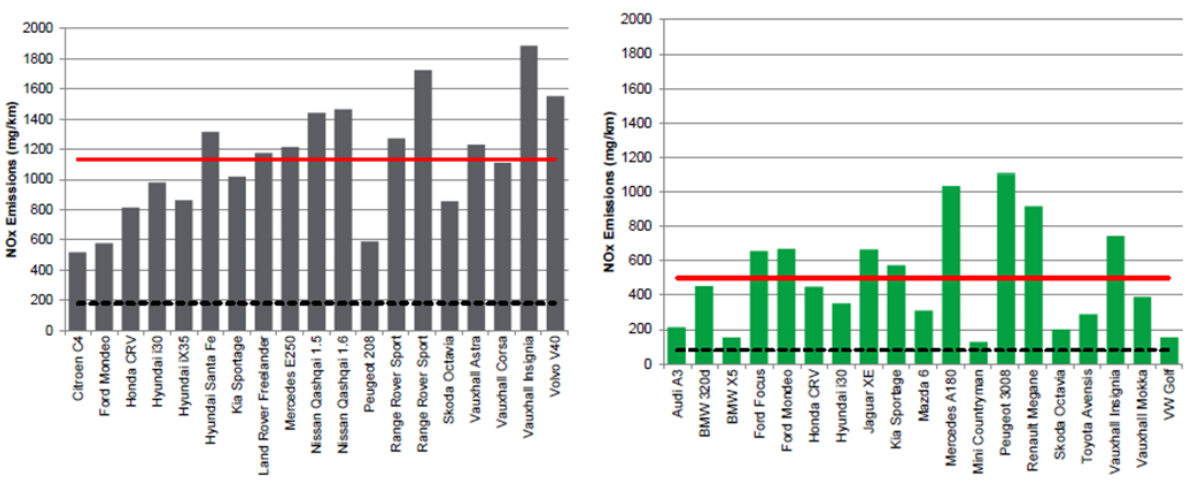

Figure 5 Real driving emissions (RDE) of certain Euro 5 (left) and Euro 6 (right) cars (red line - mean RDE, black dotted line - limits) [7] 

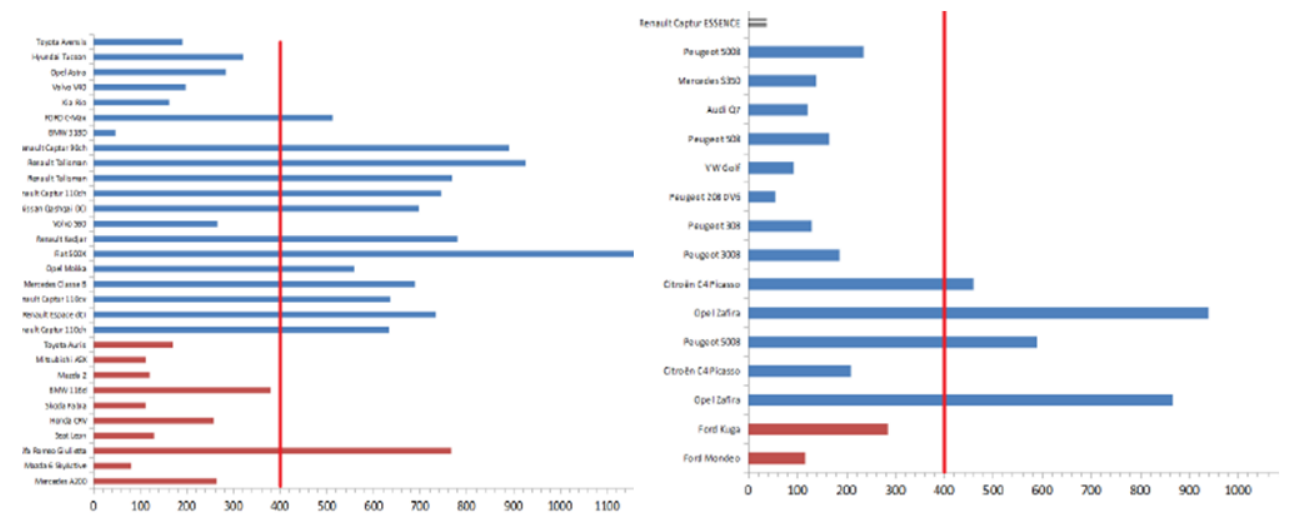

Figure $6 N O_{x}$ emissions measured on track of vehicles without SCR (left - red are with EGR only and blue are with EGR $+L N T)$ and with $S C R$ (right - red are with $S C R+E G R+L N T$ and blue with $S C R+E G R$ ) [8]

The results of Euro 6 vehicles tested in France are shown in Fig. 6 [8]. The aim of tests was to find the vehicles with $\mathrm{NO}_{\mathrm{x}}$ emission five times the limit. The vehicles were driven at open track (not in laboratory) using approval cycle NEDC (New European Driving Cycle) but in real driving conditions. The emissions values were measured using PEMS (Portable Emissions Measurement System) equipment. The worst results in RDE conditions have Euro 6 passenger cars with EGR $+\mathrm{NO}_{\mathrm{x}}$ trap (LNT): some of them five up to 15 times over the limits. The better results have Euro 6 passenger cars with SCR, but again some of them are ten times over the limits.

\section{THE REASONS FOR HIGHER EMISSIONS IN REAL DRIVING CONDITIONS}

There are two principal causes for the failure to meet limits on the road.

First, the laboratory test procedure used to measure the pollutant and $\mathrm{CO} 2$ emissions in Europe in the past is unrealistic and does not represent real-world driving conditions. The actual NEDC driving schedule practically has not transient regimes and high loads, testing conditions are almost ideal and the test is performed with specially prepared vehicle for approval. Also, there are too many flexibilities and loopholes in the testing protocols that allow carmakers to game the system.

It is allowed to carmakers to "shop around" for the best offer from the regulators that compete among themselves for type approving business. Some, for example, approval authorities KBA in Germany, CNRV in France and MIT in Italy, protect their national carmakers. Others, like the VCA in the UK, RDW in the Netherlands or SNCH in Luxembourg see type approval as a lucrative business [6].

This feeble system of approvals is exacerbated by technical services that are supposed to undertake tests but routinely only witness these in carmakers' own labs and are paid for their assistance. Sometimes the testing and approval organizations are even the same. Once the vehicle has been approved there are virtually no independent on-road checks to verify its performance in use due to a lack of will or resources. Figure 7 illustrates where are performed approval tests for first fifty cars with the high emissions in real driving 
conditions [6]. Although it is normal that carmakers perform approval tests in their own country, the national pride can be significant. It highlights that approvals are often done to support domestic manufacturers or as a business for the approval authority.

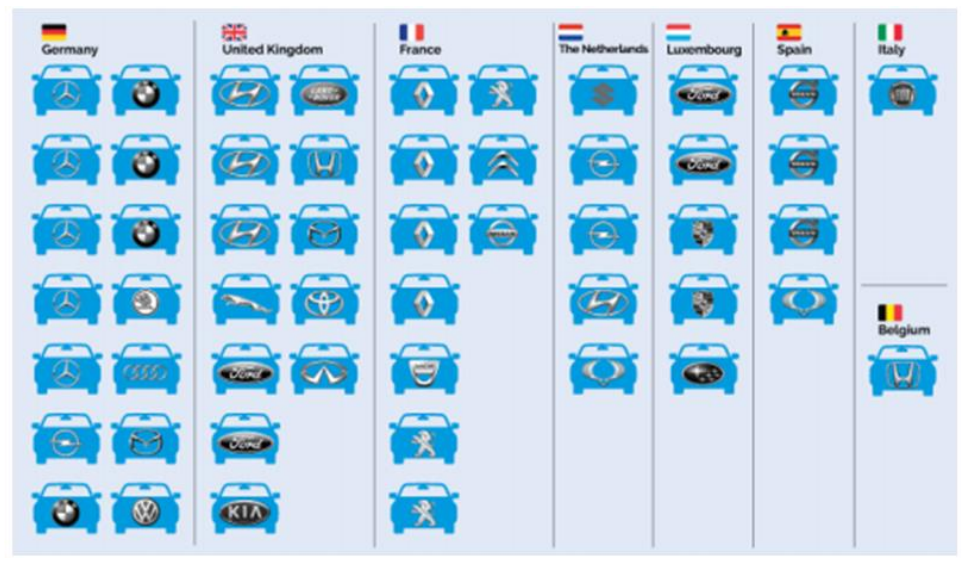

Figure 7 The figure shows which authority approved the 50 most polluting Euro 6 cars [6]

Second reason for higher $\mathrm{NO}_{\mathrm{x}}$ emissions in real driving conditions is a widespread practice of disabling emission control technologies in many conditions when the car is driven on the road. Manufacturers claim that they are utilising a legitimate loophole in the legislation. National type approval authorities have turned a blind eye to the use of defeat devices leading to such widespread health and environmental impacts.

Diesel cars are failing to operate their exhaust after-treatment systems for most of the time the car is driving, almost certainly illegally misusing a loophole in the rules governing the use of defeat strategy or defeat devices. This is done partially to improve official fuel economy figures but also due to doubts about the durability of the emissions treatment systems carmakers have chosen to use.

According to the EC regulation No. 595/2009 [9] 'defeat strategy' means an emission control strategy that reduces the effectiveness of the emission controls under ambient or engine operating conditions encountered either during normal vehicle operation or outside the type-approval test procedures. According to the ECE Regulation 83 and EC Regulation No 715/207 [2] 'defeat device' means any element of design which senses temperature, vehicle speed, engine speed (RPM), transmission gear, manifold vacuum or any other parameter for the purpose of activating, modulating, delaying or deactivating the operation of any part of the emission control system, that reduces the effectiveness of the emission control system under conditions which may reasonably be expected to be encountered in normal vehicle operation and use. use of:

Defeat strategies, i.e. the techniques which raise emissions on the road include the

1. Thermal window defeat device

2. Hot restart defeat device

3. Cycle detection defeat device.

A list of car models sold in Europe using mentioned types of defeat devices is presented in literature [6]. 
It has been identified that a lot of PC and LDV models show the presence of a "thermal window" defeat devices. These devices switch off or lower the effectiveness of the exhaust treatment systems at temperatures below those typically used during laboratory tests $\left(23-29^{\circ} \mathrm{C}\right)$. Tests conducted in late autumn, winter and early spring on track or road produced high emissions highlighting that the cars were turning down or switching off the emission control systems during these tests. Manufacturers claim such behaviour is needed to protect the engine and therefore switch off their pollution control systems bellow certain temperature (some models of Opel and Vauxhall bellow 17oC, Renault and Nissan also bellow 17oC, Daimler bellow 10oC, Peugeot bellow 5oC, etc. [6]).

The second type of defeat device relates to "hot restarts". Again a high number of the models on the road show much higher emissions after a hot engine restart than when the engine is cold. Manufacturers' explanation is that high emissions are generated by hotter engine temperatures experienced at warm restarts. However the effectiveness of the aftertreatment should be much better when hot conditions. High warm start emissions are highly suspicious and suggest that during the EU test cold start a different and more effective engine and exhaust calibration is being used.

The third defeat device relates to "test recognition" strategy. Such defeat device was described as a "switch" that "senses whether the vehicle is being tested or not based on various inputs including the position of the steering wheel, engine compartment cover, vehicle speed and load, the duration of the engine's operation, etc. It was reported that several tests by the German type approval authority (KBA) have found evidence that the exhaust treatment system in some Fiat models would switch itself off after 22 minutes (test duration is 20 minutes). Also some of Ford and Fiat models switch off their pollution control systems at high vehicle speeds and when a car is full with passengers [6]).

However, it is proved that only Volkswagen Group used the defeat device recognizing control test and switching software for emission control [10]. Fig. 8 show the results of $\mathrm{NO}_{\mathrm{x}}$ emissions during unrecognized and recognized test of Škoda passenger car. The recognition was done according to the shape of the first part of driving cycle. At normal start of standard cycle (laboratory NDEC) the engine used base emission control software enabling low emission of $\mathrm{NO}_{\mathrm{x}}$. If reverse cycle was used (first extra urban cycle and then urban cycle) the driving cycle was not recognized and the engine used auxiliary emission control software giving high $\mathrm{NO}_{\mathrm{x}}$ emissions.

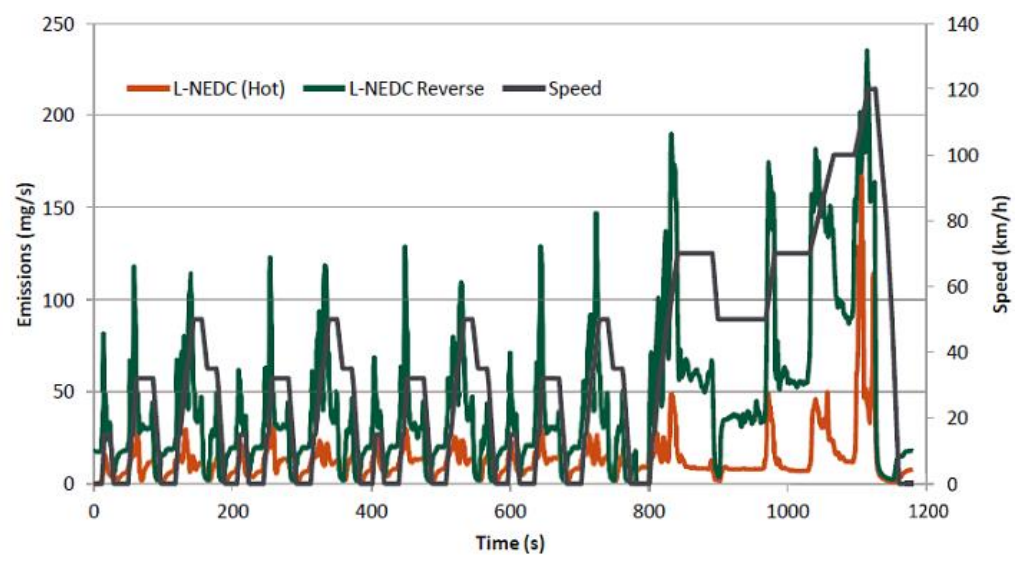

Figure 8 Test recognized (red) and unrecognized (green) NOx emission [10] 


\section{MEASURES FOR THE IMPROVEMENT OF REAL DRIVING EMISIONS}

Keeping in mind current situation, the European Commission, in cooperation with research institutions, not governmental associations and vehicle manufacturers, has undertaken regulatory measures to reduce emissions in real driving conditions. These measures have included the monitoring of current situation, the determination of possible emissions deviations in real exploitation, the improvement in the existing regulations regarding the performance of approval tests conformity checks in exploitation, the definition of emission limits in real driving conditions and the proposal of RDE control test. It is envisaged that the entire process of creating additional regulations to control emissions in real use is carried out in several steps.

The first step was already implemented in 2015 using EU research institutions in order to check the possible variations of approved $\mathrm{NO}_{\mathrm{x}}$ emission values of new vehicles comparing them with the measurements in realistic conditions. Actually it was immediately concluded that there is a high probability that the emission during real operation is greater than the value from homologation. The first reason is that during the approval the vehicle is running from cold conditions in contrary to the hot engine of vehicle used in real driving conditions. Second reason is that the environmental conditions (pressure and temperature) differ from standard conditions prescribed for the control in laboratory. Third reason is the use of different emissions control software in laboratory and in real driving. This is illustrated in Figure 9 for the same new car tested in and out the laboratory [10]. If the standard driving control cycle (NDEC) is performed with a hot engine, laboratory $\mathrm{NO}_{\mathrm{x}}$ emission already exceeds the limits by more than $50 \%$ (left side - red of figure 9). However if the test is performed outside the laboratory in real environmental conditions differences are much greater (right side - green).

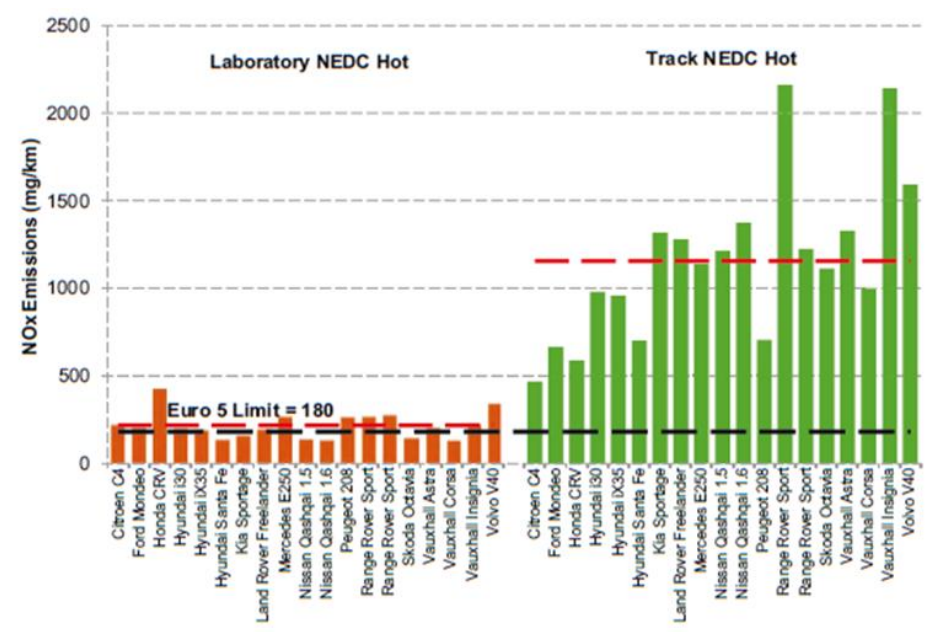

Figure 9 Laboratory versus track NOx emission of new Euro 5 vehicles [10]

Based on these measurements, so-called Conformity Factor, defined as the ratio between real NOx emission and standard limit, should be establish. The Conformity Factor will be then used to define the maximum allowed NOx emission in real driving conditions, so called Not To Exceed (NTE) limit, according to the expression

NTE limit $=$ Conformity factor $x$ Euro 6 limit 
On the October 2nd 2015 European Commission sent the proposal [11] on so called First RDE package to the EU Council and on 10 November 2015, the Council gave its green light to the adoption of the first package of rules on real driving emission (RDE) tests to measure pollutants emissions of light vehicles. This first package introduces the concept of RDE procedures with a portable emissions measurement system. It will apply from 1 January 2016. At this initial stage the system will be used only for monitoring purposes. It will therefore not yet have any implications on the approval of new models.

During the discussion about future conformity factors, the European Commission had proposed significantly more stringent limits applying conformity factors of 1.6 in the short term and 1.2 in the longer term, but a lot of Member states suggest much higher values [12]. On the 28 October 2015, the European Commission and Member states reached an agreement on the Second RDE package establishing implementation dates and conformity factors on NOx RDE. On 12 February 2016, the Council gave its green light to the adoption of the second package of rules with real driving emission (RDE) limits. According to this package 2.1 short term and 1.5 long term conformity factors are adopted. This second conformity factor will be annually reviewed to take into consideration technical improvements to the test equipment during RDE control test definition. The implementation dates of RDE limits for new model type approvals and for all new vehicles are shown in Figure 10 [12].

\begin{tabular}{|c|c|c|}
\hline & New Type Approvals & All vehicles \\
\hline 1.1.2016 & & Testing commences \\
\hline 1.9.17 & $\begin{array}{c}\text { Not to exceed limit } \\
168 \mathrm{mg} / \mathrm{km}\end{array}$ & \\
\hline 1.9 .19 & & $\begin{array}{c}\text { Not to exceed limit } \\
168 \mathrm{mg} / \mathrm{km}\end{array}$ \\
\hline 1.9 .20 & $\begin{array}{l}\text { Not to exceed limit } \\
120 \mathrm{mg} / \mathrm{km}\end{array}$ & \\
\hline 1.9.21 & & $\begin{array}{l}\text { Not to exceed limit } \\
120 \mathrm{mg} / \mathrm{km}\end{array}$ \\
\hline
\end{tabular}

Figure 10 RDE limits and implementation dates [12]

Meanwhile the discussion on RDE control test continued. Proposal of Third RDE package includes three important items [13]:

a) Particle number (PN) PEMS RDE testing. PN PEMS testing seems to be possible, albeit with somewhat higher uncertainties than the $\mathrm{NO}_{\mathrm{x}}$ PEMS testing. The results of the testing at the JRC as well as of the interlaboratory exercise were presented at the RDE-LDV meeting of 20th April 2016. [14, 15].

b) Coverage of the vehicle cold start. There are two possibilities: to include the cold start data in the normal RDE data evaluation and to calculate separately the contribution of the cold start and weighing it in the RDE data evaluation [16].

c) Special RDE testing conditions for hybrids. All hybrids should be certifiable with the RDE procedure and appropriate evaluation methods need to be developed [17]. 
In September 2016 also started consideration of Fourth RDE package which should cover the definition of in-use-conformity RDE testing including the concepts developed by the "RDE surveillance task force" [13].

All agreed items are included in EU Commission Regulation 2016/646 from April 20, 2016 [18]. This Regulation defines two emissions strategies: 'base emission strategy' that is active throughout the speed and load operating range of the vehicle, and 'auxiliary emission strategy' that becomes active and replaces or modifies a BES for a specific purpose and in response to a specific set of ambient or operating conditions and only remains operational as long as those conditions exist. Appendix 6 to Annex I of this Regulation introduces Euro $6 \mathrm{c}$ and $6 \mathrm{~d}$ standards for different classes of vehicles supplied by gasoline, diesel, E10 and B7 fuels. The implementation dates are defined according to norm levels and vehicle classes with the application from 1.9.2017 to 1.1.2022. RDE testing is also included with NTE limits. Annex II of this regulation defines final and temporary NTE limits as well as proposal of procedure of RDE control test with the verification and calculation of testing results.

New requirements for low real driving emissions need the application of new more expensive technologies. It is concluded that Euro 6 light vehicles with real-world compliance are technically feasible, even with stringent RDE requirements. Therefore, EGR system, frequently used in light vehicles, will be probably change to SCR system which gives smaller deviations in real use. The additional production costs of vehicle equipped with SCR can be up to $€ 500$.

Taking in account all undertaken measures it is expecting that in 2021 approval and in use emissions data will be closer. The forecast is shown in Figure 10.

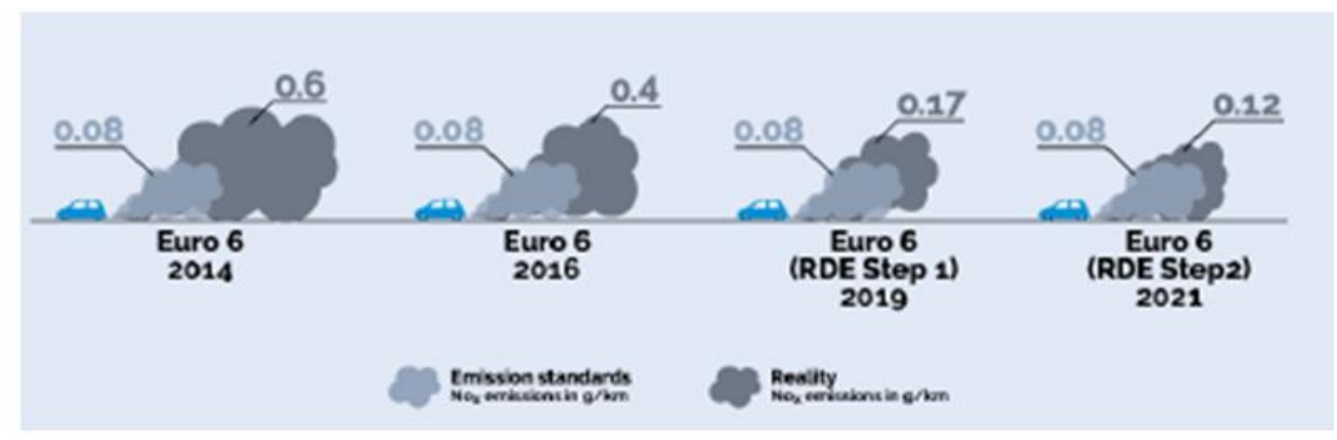

Figure 10 The forecast of future NOx emission according to EU standards and in real driving conditions [6]

\section{CONCLUSIONS}

NOx emissions of light vehicles is several times higher in real driving conditions than in laboratory during approval test. It is higher by a factor of 2 for Euro 3 vehicles, more than three times for Euro 4, four times for Euro 5 and seven times for Euro 6 vehicles.

The main reasons for higher $\mathrm{NO}_{\mathrm{x}}$ emissions in real driving conditions are:

1. The standard test procedure used to measure the pollutant in laboratory is unrealistic and does not represent real-world driving conditions. 
2. The manufacturers of diesel cars are failing to operate their exhaust aftertreatment systems for most of the time the car is driven with the aim to improve fuel economy as well as to keep the durability of the emissions treatment systems they have chosen to use.

EU Commission has undertaken certain regulatory measures to improve the level of NOx emissions in real driving conditions. These measures involve the adoption of socalled „RDE Packages“. The proposals of First and Second RDE packages are already accepted and Third and Fourth are under consideration. Their conclusions will be included in EU Regulation 2016/646 with adopted conformity factors (defining permitted deviation between standard limits and real driving data), temporary and final NTE (Not To Exceed) limits with the implementation dates, real driving emissions (RDE) test procedure, and validation and calculation of test data.

\section{ACKNOWLEDGEMENT}

The authors with to thanks TEHNOLAB, Centre for Motore Vehicle, Belgrade for financial and official support in the collection of literature and data on the problem of real driving emissions and in the participation of real driving emissions programm.

\section{REFERENCES}

[1] Walsh M. P., The Future of Vehicle Emissions Regulation in the EU and Internationally, International Council for Clean Transportation, June 5, 2013, http://ec.europa.eu/environment/archives/greenweek2013/sites/default/files/content /presentations/5-4_walsh.pdf.

[2] REGULATION (EC) No 715/2007 OF THE EUROPEAN PARLIAMENT AND OF THE COUNCIL, 2007, http://eur-lex.europa.eu/LexUriServ/LexUriServ.do?uri $=\mathrm{OJ}: \mathrm{L}: 2007: 171: 0001: 0016: \mathrm{EN}:$ PDF.

[3] Franco V., Mock P., Real driving emissions: Challenges to regulating diesel engines in Europe, IICT Anil Agarwal Dialogue. New Delhi, March 11-12 2015, http://www.cseindia.org/docs/aad2015/ICCT-Anil-Agarwal-EU-Diesel3-2015.pdf.

[4] Jan Cortvriend, Emission reductions resulting from the implementation of the Euro standards, EU Commission, CLRTAP 52nd WGSR, 30 June -3 July 2014, https://www.unece.org/fileadmin/DAM/env/documents/2014/AIR/WGSR/1_Cortvr iend_WGSR_2014_Transport_emissions_V2.pdf.

[5] Defeat devices under the U.S. and EU passenger vehicle emissions testing regulations, IICT Briefing, March 2016, http://www.theicct.org/sites/default/files/ publications/ICCT_defeat-devices-reg-briefing_20160322.pdf.

[6] „Diesel gate: Who? What? How?“, Study by Transport \& Environment, Final report, September 2016, https://www.transportenvironment.org/sites/te/files/2016_09_Dieselgate_report_w ho_what how FINAL_0.pdf.

[7] Vehicle Emissions Test Programme October 2015 -April 2016, UN ECE GRPE Inf. Doc. 73/27, 2016, https://www.unece.org/fileadmin/DAM/trans/doc/2016 wp29grpe/ GRPE-73-27.pdf.

[8] Contrôle des émissions de polluants atmosphériques et de $\mathrm{CO} 2$ mené sur 86 véhicules, Rapport final de la commission indépendante, Ministere de 
Environment, de Energy et de Mer, July 2016., http://www.developpementdurable.gouv.fr/IMG/pdf/ Rapport_Commission_independante.pdf.

[9] REGULATION (EC) No 595/2009 OF THE EUROPEAN PARLIAMENT AND OF THE COUNCIL, Official Journal of the EU, L 188/1, 18.7.2009, http://eurlex.europa.eu/LexUriServ/LexUriServ.do?uri=OJ:L:2009:188:0001:0013:EN:PDF.

[10] Vehicle Emissions Testing Programme, Moving Britain Ahead, Department for Transport, April 2016, https://www.gov.uk/government/uploads/system/uploads/ attachment_data/file/548148/vehicle-emissions-testing-programme-web.pdf.

[11] COMMISSION REGULATION (EU) .../..., Council of the EU, 12353/1/15 Rev. 1, Brussels, 2 October 2015, http://data.consilium.europa.eu/doc/document/ST12353-2015-REV-1/en/pdf.

[12] Real-world Driving Emissions tests: the facts, Transport\&Environment, Dec. 2015, http://influencemap.org/site/data/000/126/Transport\&Environment_RDE_MS_Dec ember_22_2015.pdf.

[13] Real driving emission (RDE) legislation: updated next steps, EC DirectorateGeneral for Internal Market, Industry, Entrepreneurship and SMEs, Brussels, 19/04/16,

https://circabc.europa.eu/webdav/CircaBC/GROW/automotive/Library/comitology _committees/technical_committee/56th\%20meeting\%20on\%2021\%20April\%2020 16/RDE\%20legislation\%20\%20next\%20steps\%20rev\%20April\%202016\%20vs3.p df.

[14] $\overline{\text { PN }}$ - PEMS Progress Update V3, JRC, EC RDE-LDV meeting, 20 April 2016, https://circabc.europa.eu/webdav/CircaBC/GROW/wltp/Library/meetings/RDELDV\%20meetings\%202015\%20-/160420\%20-\%20RDE-LDV/20160420_PNPEMS_progress\%20update\%20v3.pdf.

[15] B. Giechaskiel, F. Riccobono, M. Weiss, Real-Driving Emissions (RDE): Update on Particle Number (PN) measurements with Portable Emission Measurement Systems (PEMS), EC JRC, RDE-LDV meeting, 1 June 2016, Stuttgart,http://www.ukintpressconferences.com/uploads/SPKEX16/d2_s0_p1_bar ouch giechaskiel.pdf.

[16] RDE cold-start provisions, Contribution to the RDE working group, EC JRC, 20 April,2016,https://circabc.europa.eu/webdav/CircaBC/GROW/wltp/Library/meetin gs/RDE-LDV\%20meetings\%202015\%20-/160420\%20-\%20RDE LDV/20160420_Cold-start_draft_final\%202.pdf.

[17]RDE testing of hybrid vehicles, EC LDV meeting, 20 April 2016, https://circabc.europa.eu/webdav/CircaBC/GROW/wltp/Library/meetings/RDELDV\%20meetings\%202015\%20-/160420\%20-\%20RDE-LDV/20160420_Hybridvehicles_final.pdf.

[18] COMMISSION REGULATION (EU) 2016/646, Official Journal of the European Union,L109/1,26.4.2016,http://eur-lex.europa.eu/legal-content/EN/TXT/PDF/?uri= CELEX:32016R0646\&from=en. 